\title{
An Efficient Synthesis of Substituted Chrysenes
}

Lee Eccleshare*, Sean Selzer, Simon Woodward ${ }^{[a]}$

[a] L. Eccleshare, S. Selzer, Prof. Dr. S. Woodward, School of Chemistry, University of Nottingham, University Park, Nottingham NG7 2RD (United Kingdom)

E-mail: Lee.Eccleshare@outlook.com

Supporting information for this article is available (end of manuscript)

Abstract: Substituted chrysenes have been swiftly synthesised by the 6-endo-dig cyclisation of ethynylnaphthalenes using platinum(II) chloride. Cyclisation precursors were directly prepared from commercially available 2-bromoaldehydes in a telescoped synthetic procedure involving a Cannizzaro triggered cascade and subsequent dehydration and desilylation. This short synthetic procedure allows rapid access to derivatives of biologically active molecules with useful electronic properties.

\section{Introduction}

Chrysene $\left(\mathrm{C}_{18} \mathrm{H}_{12}\right)$ is a polycyclic aromatic hydrocarbon (PAH) that is formed during incomplete combustion of carbon rich fuels ${ }^{[1]}$ and was the first PAH to be discovered in uncontaminated soil samples. ${ }^{[2]}$ Whilst several studies have shown that chrysene and its metabolites, ${ }^{[3]}$ trans-1,2dihydroxy-1,2-dihydrochrysene and trans-3,4-dihydroxy-3,4-dihydrochrysene (Scheme 1a) are carcinogenic and mutagenic, ${ }^{[4]}$ it has also been reported that some substituted chrysenes, due to their DNA intercalating nature, show anticancer activity. ${ }^{[5]}$ Due to their electronic properties chrysenes also have synthetic uses as single electron transfer mediators, ${ }^{[6]}$ mechanistic probes ${ }^{[7]}$ and have applications in the field of organic electronics. ${ }^{[8,9]}$ The two most common synthetic routes to chrysenes are the photochemical cyclisations of styrylnaphthalenes ${ }^{[10]}$ and metal catalysed cyclisations of aromatic acetylenes. ${ }^{[8,11]}$ Our efficient synthesis allows the rapid formation of substituted chrysenes, under simple, benign conditions from readily available commercial materials. As we are able to design chrysene substrates with substitution on both terminal rings and also access substitution patterns that are difficult to control with other synthetic methods ${ }^{[10]}$ (controlled substitution in the 2- and 4positions), this work is perfectly complimentary to that which has already been published. 
a)<smiles>c1ccc2c(c1)ccc1c3ccccc3ccc21</smiles>

Chrysene

b)<smiles>[R]C#Cc1c(-c2ccc(C(F)(F)F)cc2)ccc2ccc(F)cc12</smiles>

(1) $R=T M S$

(2a) $\mathrm{R}=\mathrm{H}$<smiles>OC1c2ccc3c(ccc4ccccc43)c2C=C[C@@H]1O</smiles>

trans-1,2-dihydroxy-1,2-dihydrochrysene<smiles>Fc1ccc2ccc3c4ccc(C(F)(F)F)cc4ccc3c2c1</smiles>

(3a)

Scheme 1. a) The numbering of chrysene and a carcinogenic metabolite; b) Compounds from the preliminary investigation.

\section{Results and Discussion}

Recent work carried out within our group ${ }^{[12]}$ highlighted how cascade reactions based around an unusual Cannizzaro like 1,5-hydride transfer ${ }^{[13]}$ can be used to rapidly develop complex molecules, such as 1 (Scheme 1b), from commercially available 2-bromoaldehydes. We envisaged using a platinum(II) chloride catalysed, 6-endo-dig cyclisation $^{[8,11 a]}$ to attain a substituted chrysene from ethynylnaphthalene 1 . Under our initial conditions, heating to reflux with $5 \mathrm{~mol} \%$ platinum(II) chloride in toluene, for a protracted reaction time of 65 hours, we observed $58 \%$ conversion to the desilylated chrysene 3a (Scheme 1b). Formation of the silylated chrysene was not observed. Unsatisfied with the long reaction times and incomplete conversion, more efficient reaction conditions were sought. The rate of reaction could be significantly increased by microwave heating to $150{ }^{\circ} \mathrm{C}$ in a sealed tube. As the formation of silyl-3a was not observed, it was considered that the sluggish annulation could be due to a slow desilyation of naphthalene $\mathbf{1}$ followed by the much faster annulation of the resultant terminal acetylene. When terminal acetylene $\mathbf{2 a}$, the desilylated derivative of $\mathbf{1}$, was subjected to 150 ${ }^{\circ} \mathrm{C}$ microwave heating in the presence of 5 mol\% platinum(II) chloride, complete consumption of the starting material was achieved within 1 hour.

In order to generalise this new synthetic route to chrysenes as efficiently as possible, we telescoped the synthesis of ethynylnaphthalenes using our Cannizzaro cascade procedure (Scheme 2). The cascade procedure ${ }^{[12]}$ affords crude 1,2-dihydronaphthalen-1-ol 7 which could be directly dehydrated using Amberlyst $15^{\circledR}$ to give silylated ethynylnaphalene 8. Subsequent addition of tetrabutylammonium fluoride solution to the reaction mixture followed by a single purification leads directly to ethynylnaphthalene $\mathbf{2}$ in up to $70 \%$ yield in a single synthetic session. 
<smiles>[R]c1ccc(Br)c(C=O)c1</smiles>

(4)

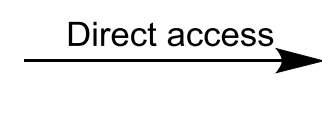

i) $\mathrm{LiCCTMS}$
ii) $n \mathrm{BuLi}$
iii) $\mathrm{CuBr} \bullet \mathrm{SMe}_{2}$
iv) $\left(\mathrm{C}_{6} \mathrm{H}_{4} \mathrm{R}^{2}\right) \mathrm{CHCICCH}$<smiles>[R]c1cccc(C=Cc2ccc([R1])cc2C(O)C#CC(C)C)c1</smiles>

(5)

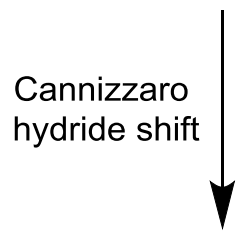<smiles>[Y16]C#CC(=O)c1cc([R1])ccc1/C=C\Cc1ccccc1</smiles>

(6)<smiles>[R]c1ccc(-c2ccc3ccc([R])cc3c2C#C)cc1</smiles>

(2)

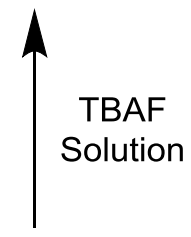<smiles>[R]c1ccc2ccc(-c3ccccc3)c(C#CC(C)(C)C)c2c1</smiles>

(8)
Amberlyst $15^{\circledR}$

$3 \AA$ Å mol. sieves

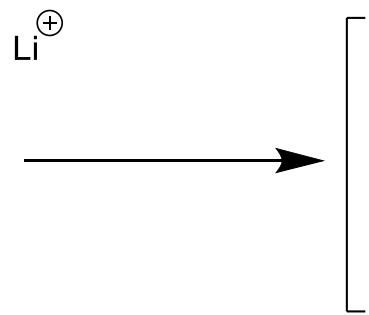<smiles>[R]c1ccc2c(c1)C(O)(C#CS(C)(=O)=O)[C@H](c1ccccc1)C=C2</smiles>

(7)

Scheme 2. Telescoped synthesis of ethynylnapthalene $\mathbf{2}$.

The scope of the telescoped route is shown in Table 1 by the synthesis of a range of ethynylnaphthalenes (2a-f). When the $\mathrm{R}^{2}$ substituent is an electron withdrawing $p$-trifluoromethyl group (2a-c) the aromatic aldehyde can tolerate electron withdrawing, electron donating and electron neutral substitution and achieve yields of $45-67 \%$. Functional groups are also tolerated in the $\mathrm{R}^{2}$ position with $p$-methyl ester (2d) and $m$-nitrile (2f) substitution giving yields of $61 \%$ and $70 \%$, respectively. Only when using a mildly electron withdrawing $R^{2}$ substituent, o-fluoro (2e), was a significant drop in yield observed. This is mainly due to a competing reaction pathway in which the Cannizzaro cascade forms a fused 8-membered ring in place of the 1,2-dihydronaphthalen-1-ol. This observation was not unexpected and is in line with our previous work. ${ }^{[12]}$

Table 1. Scope of the telescoped Cannizzaro cascade procedure. 
<smiles>[R]c1ccc(Br)c(C=O)c1</smiles>

(4)

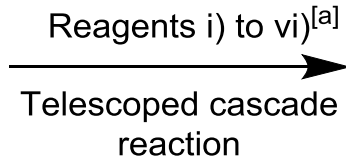
reaction<smiles>[R]c1ccc(-c2ccc3ccc([R])cc3c2C#C)cc1</smiles>

(2a-f)

\begin{tabular}{cccc}
\hline $\mathrm{R}^{1}$ & $\mathrm{R}^{2}$ & Product & Yield $(\%)^{[\mathrm{b}]}$ \\
\hline $\mathrm{F}$ & $p-\mathrm{CF}_{3}$ & $\mathbf{2 a}$ & 58 \\
$\mathrm{OMe}$ & $p-\mathrm{CF}_{3}$ & $\mathbf{2 b}$ & 45 \\
$\mathrm{H}$ & $p-\mathrm{CF}_{3}$ & $\mathbf{2 c}$ & 67 \\
$\mathrm{H}$ & $p-\mathrm{CO}_{2} \mathrm{Me}$ & $\mathbf{2 d}$ & 61 \\
$\mathrm{H}$ & $0-\mathrm{F}$ & $\mathbf{2 e}$ & 23 \\
$\mathrm{H}$ & $m-\mathrm{CN}$ & $\mathbf{2 f}$ & 70
\end{tabular}

Reaction conditions: i) LiC $\equiv$ CTMS $(6.9 \mathrm{~mL}$ of $0.50 \mathrm{M}$ THF-hexane solution) treated with 2bromoaldehyde $\left(3.24 \mathrm{mmol}\right.$ ) at $-50{ }^{\circ} \mathrm{C}$; ii) $n$ BuLi (3.40 mmol); iii) $\mathrm{CuBr} \cdot \mathrm{SMe}_{2}$ (1.63 mmol); iv) $\mathrm{R}^{2} \mathrm{ArCCIC} \equiv \mathrm{CH}$, warmed to $0{ }^{\circ} \mathrm{C}$; v) Amberlyst $15^{\circledR}$ and $3 \AA$ molecular sieves at room temperature; vi) TBAF solution ( $1 \mathrm{M}$ in THF, $6.5 \mathrm{mmol})$. ${ }^{\text {[a] }}$ Full description of reaction conditions available in supplementary data. ${ }^{[b]}$ isolated yield.

Substrates 2a-f were used to assess the generality of the platinum(II) chloride catalysed synthesis of substituted chrysenes. Using the optimal conditions from our preliminary work, chrysenes 3a-f were synthesised in $31-81 \%$ yield (Table 2). Substrates $\mathbf{2 a - b}$, with the $p$-trifluoro methyl $\mathrm{R}^{2}$ substituent, perform well in the cyclisation giving $\mathbf{3 a - b}$ in $71 \%$ and $66 \%$ yields respectively. The closely related $\mathbf{3 c}$ has a slightly lower yield of $51 \%$, this could be in part due to its very poor solubility making purification challenging. Ester $\mathbf{3 d}$ was synthesised in $65 \%$ yield, albeit with an extended reaction time of 2 hours needed to achieve full consumption of the starting material. The highest yielding chrysene was 4fluoro substituted $\mathbf{3 e}$ attained in an impressive $83 \%$ yield.

Table 2. Formation of substituted chrysenes 3a-f.<smiles>[R]c1ccc(-c2ccc3ccc([R])cc3c2C#C)cc1</smiles>

(2a-f)

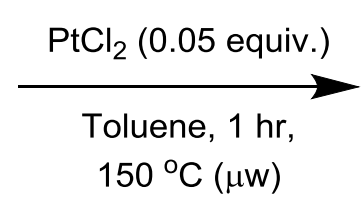

$150^{\circ} \mathrm{C}(\mu \mathrm{w})$

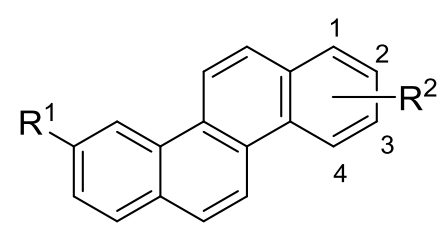

(3a-f)

\begin{tabular}{cccc}
\hline $\mathrm{R}^{1}$ & $\mathrm{R}^{2}$ & Product & Yield $(\%)^{[\mathrm{a}]}$ \\
\hline $\mathrm{F}$ & $p-\mathrm{CF}_{3}$ & $\mathbf{3 a}$ & 71 \\
$\mathrm{OMe}$ & $p-\mathrm{CF}_{3}$ & $\mathbf{3 b}$ & 66 \\
$\mathrm{H}$ & $p-\mathrm{CF}_{3}$ & $\mathbf{3 c}$ & 51 \\
$\mathrm{H}$ & $p-\mathrm{CO}_{2} \mathrm{Me}$ & $\mathbf{3 d}$ & $65^{[\mathrm{b}]}$ \\
$\mathrm{H}$ & $\mathrm{o}-\mathrm{F}$ & $\mathbf{3 e}$ & 83 \\
$\mathrm{H}$ & $m-\mathrm{CN}$ & $\mathbf{3 f}$ & $31^{[\mathrm{c}]}$
\end{tabular}


[a] Isolated yield. ${ }^{[b]}$ Microwave heating was continued for a total of 2 hours to achieve complete consumption of starting material. ${ }^{[c]}$ Product was isolated as a 12:1 mixture of regioisomers favouring substitution at the 3 position versus the 1 position.

Substrate $\mathbf{2} \mathbf{f}$ was chosen for this study to assess the regioselectivity of the cyclisation as both possible chrysene products have published ${ }^{1} \mathrm{H}$ NMR spectroscopic data. ${ }^{[10 a]}$ Gratifyingly, inspection of our own sample showed that we obtained high regioselectivity with a 12:1 ratio favouring the formation of 3-nitrile substitution over 1-nitrile substitution. The lower yield of chrysene $\mathbf{3} f$ is thought to be caused by a competing polymerisation pathway involving the nitrile group.

\section{Conclusion}

We have developed a new, step efficient, synthetic route to substituted chrysenes. Application of a one-pot Cannizzaro cascade procedure followed by telescopic dehydration and desilylation gives swift access to ethylnylnaphthalenes from very simple precursors. Formation of chrysenes can be achieved via platinum(II) chloride catalysed annulation under microwave heating. This overall synthetic sequence shows how one-pot reactions can be used to rapidly build up molecular complexity and access derivatives of valuable biologically active targets.

\section{Acknowledgements}

LE would like to thank the University of Nottingham for the provision of a studentship.

\section{Supplementary Material}

Full experimental and spectroscopic data for all novel compounds has been made available.

\section{References}

[1] Simoneit, B. R. T. Appl. Geochem. 2002, 17, 129.

[2] Kern W. Helv. Chim. Acta. 1947, 30, 1595.

[3] Jacob, J.; Doehmer, J.; Grimmer, G.; Soballa, V.; Raab, G.; Siedel, A.; Greim, H. Polycyclic Aromat. Compd. 1996, 10, 1.

[4] (a) Ali, D.; Verma, A.; Mujtaba, F.; Dwivedi, A.; Hans, R. K.; Ray, R. S. Toxicol. Lett. 2011, 204, 199; (b) Wood, A. W.; Chang, R. L.; Levin, W.; Yagi, H.; Tada, M.; Vyas, K. P.; Jerina, D. M.; Conney, A. H. Cancer Res. 1982, 42, 2972; (c) Slaga, T. J.; Gleason, G. L.; Mills, G.; Ewald, L.; Fu, P.P.; Lee, H.M.; Harvey, R. G. Cancer Res. 1980, 40, 1981; (d) Chang, R.L.; Levin, W.; Wood, A. W.; Yagi, H.; Tada, M.; Vyas, K. P.; Jerina, D. M.; Conney, A. H. Cancer Res. 1983, 43, 192; (e) Bigelow, S. W.; Nebert, D. W. Toxicol. Lett. 1982, 10, 109.

[5] (a) Bandyopadhyay, D.; Granados, J. C.; Short, J. D.; Banik, B. K. Oncol. Lett. 2012, 3, 45; (b) Banik, B.; Becker, F. F. Eur. J. Med. Chem. 2010, 45, 4687.

[6] (a) Yoshimi, Y.; Hayashi, S.; Nishikawa, K.; Haga, Y.; Maeda, K.; Morita, T.; Itou, T.; Okada, Y.; Ichinose, N.; Hatanaka, M. Molecules 2010, 15, 2623; (b) Lund, H.; Michel, M.; Simonet, J. Acta Chem. Scand. 1974, 28B, 900.

[7] (a) Chatterjee, S.; Davis, P. D.; Gottschalk, P.; Kurz, M. E.; Sauerwein, B.; Yang, X.; Schuster, G. J. Am. Chem. Soc. 1990, 112, 6329; (b) Ashby, E. C.; Goel, A. B.; DePriest, R. N. J. Org. Chem. 1981, 46, 2429.

[8] Wu, T.; Chou, H.; Huang, P.; Cheng, C.; Liu, R. S. Org. Chem. 2014, 79, 267.

[9] Ionkin, A. S.; Marshall, W. J.; Fish, B. M.; Bryman, L. M.; Wang, Y. Chem. Commun. 2008, 2319. [10] (a) Gore, P. H.; Kamonah, F.S. Synthesis 1978, 773; (b) Nagel, D. L.; Kupper, R.; Antonson, K.; Wallcave, L. J. Org. Chem. 1977, 42, 3626; (c) Blackburn, E. V.; Loader, C. E.; Timmons, C. J. J. Chem. Soc. C 1970, 163. 
Eccleshare, Selzer, Woodward - Manuscript for Tetrahedron Lett.

[11] (a) Fürstner, A.; Mamane, V. J. Org. Chem. 2002, 67, 6264; (b) Das, A.; Liao, H.; Lui, R. S. J. Org. Chem. 2007, 72, 9214.

[12] Eccleshare, L.; Lozada-Rodríguez, L.; Cooper, P.; Burroughs, L.; Ritchie, J.; Lewis, W.; Woodward, S. Chem. Eur. J. 2016, 22, 12542.

[13] Burroughs, L.; Eccleshare, L.; Ritchie, J.; Kulkarni, O.; Lewis, W.; Lygo, B.; Woodward, S. Angew. Chem. Int. Ed. 2015, 54, 10648. 